\title{
Front Matter: Volume 8032
}

, "Front Matter: Volume 8032," Proc. SPIE 8032, Next-Generation

Spectroscopic Technologies IV, 803201 (6 July 2011); doi: 10.1117/12.900052

SPIE Event: SPIE Defense, Security, and Sensing, 2011, Orlando, Florida, United SPIE. States 


\section{PROCEEDINGS OF SPIE}

\section{Next-Generation Spectroscopic Technologies IV}

Mark A. Druy

Richard A. Crocombe

Editors

25-26 April 2011

Orlando, Florida, United States

Sponsored and Published by

SPIE

Volume 8032

Proceedings of SPIE, 0277-786X, v. 8032 
The papers included in this volume were part of the technical conference cited on the cover and title page. Papers were selected and subject to review by the editors and conference program committee. Some conference presentations may not be available for publication. The papers published in these proceedings reflect the work and thoughts of the authors and are published herein as submitted. The publisher is not responsible for the validity of the information or for any outcomes resulting from reliance thereon.

Please use the following format to cite material from this book:

Author(s), "Title of Paper," in Next-Generation Spectroscopic Technologies IV, edited by Mark A. Druy, Richard A. Crocombe, Proceedings of SPIE Vol. 8032 (SPIE, Bellingham, WA, 2011) Article CID Number.

ISSN 0277-786X

ISBN 9780819486066

Published by

SPIE

P.O. Box 10, Bellingham, Washington 98227-0010 USA

Telephone +1 3606763290 (Pacific Time) · Fax +1 3606471445

SPIE.org

Copyright (C) 2011, Society of Photo-Optical Instrumentation Engineers

Copying of material in this book for internal or personal use, or for the internal or personal use of specific clients, beyond the fair use provisions granted by the U.S. Copyright Law is authorized by SPIE subject to payment of copying fees. The Transactional Reporting Service base fee for this volume is $\$ 18.00$ per article (or portion thereof), which should be paid directly to the Copyright Clearance Center (CCC), 222 Rosewood Drive, Danvers, MA 01923. Payment may also be made electronically through CCC Online at copyright.com. Other copying for republication, resale, advertising or promotion, or any form of systematic or multiple reproduction of any material in this book is prohibited except with permission in writing from the publisher. The CCC fee code is 0277-786X/11/ \$18.00.

Printed in the United States of America.

Publication of record for individual papers is online in the SPIE Digital Library.

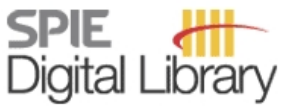

SPIEDigitalLibrary.org

Paper Numbering: Proceedings of SPIE follow an e-First publication model, with papers published first online and then in print and on CD-ROM. Papers are published as they are submitted and meet publication criteria. A unique, consistent, permanent citation identifier (CID) number is assigned to each article at the time of the first publication. Utilization of CIDs allows articles to be fully citable as soon as they are published online, and connects the same identifier to all online, print, and electronic versions of the publication. SPIE uses a six-digit CID article numbering system in which:

- The first four digits correspond to the SPIE volume number.

- The last two digits indicate publication order within the volume using a Base 36 numbering system employing both numerals and letters. These two-number sets start with $00,01,02,03,04$, $05,06,07,08,09,0 A, 0 B \ldots 0 Z$, followed by 10-1Z, 20-2Z, etc.

The CID number appears on each page of the manuscript. The complete citation is used on the first page, and an abbreviated version on subsequent pages. Numbers in the index correspond to the last two digits of the six-digit CID number. 


\section{Contents}

vii Conference Committee
ix Introduction

SESSION 1 ENABLING TECHNOLOGIES

803203 Light focusing by chirped waveguide grating coupler [8032-02]

P. Kumar, Wayne State Univ. (United States); B. Bergner, D. Cook, Spectum Scientific, Inc.

(United States); I. Avrutsky, Wayne State Univ. (United States)

803205 MEMS-based tunable Fabry-Perot filters [8032-04]

N. Gupta, U.S. Army Research Lab. (United States); S. Tan, D. R. Zander, Smart Systems

Technology and Commercialization Ctr. (United States)

\section{SESSION 2 LASER-BASED AND CAVITY RINGDOWN SPECTROMETRY I}

803206 Microsensors based on quantum cascade lasers [8032-05]

S. Wu, A. Deev, Y. Tang, PEER Institute (United States) and California Institute of Technology (United States)

803207 Development of a field-deployable isotopic $\mathrm{N}_{2} \mathrm{O}$ analyzer based on mid-infrared cavity ring-down spectroscopy [8032-06]

X. Du, A. D. Farinas, E. R. Crosson, Picarro, Inc. (United States); D. Balslev-Clausen, T. Blunier, Niels Bohr Institute, Univ. of Copenhagen (Denmark)

803208 Mid-infrared absorption spectroscopy using quantum cascade lasers [8032-07]

F. Haibach, A. Erlich, E. Deutsch, Block Engineering, LLC (United States)

803209 Precision and accuracy of miniature tunable diode laser absorption spectrometers [8032-08]

M. B. Frish, R. T. Wainner, M. C. Laderer, K. R. Parameswaran, D. M. Sonnenfroh, M. A. Druy, Physical Sciences Inc. (United States)

\section{SESSION 3 LASER-BASED AND CAVITY RINGDOWN SPECTROMETRY II}

8032 OC Quantum cascade laser-based substance detection: approaching the quantum noise limit [8032-10]

P. C. Kuffner, K. J. Conroy, T. K. Boyson, G. Milford, M. A. Mabrok, A. G. Kallapur, I. R. Petersen, The Univ. of New South Wales (Australia); M. E. Calzada, T. G. Spence, Loyola Univ. New Orleans (United States); K. P. Kirkbride, Australian Federal Police (Australia); C. C. Harb, The Univ. of New South Wales (Australia) 
8032 OD Small low-power consumption CO-sensor for post-fire cleanup aboard spacecraft [8032-1 1] J. L. Bradshaw, J. D. Bruno, K. M. Lascola, R. P. Leavitt, J. T. Pham, F. J. Towner, Maxion Technologies, Inc. (United States); D. M. Sonnenfroh, K. R. Parameswaran, Physical Sciences Inc. (United States)

8032 OE Intracavity laser absorption spectroscopy using mid-IR quantum cascade laser [8032-12] G. Medhi, Univ. of Central Florida (United States); A. V. Muravjov, H. Saxena, Zyberwear, Inc. (United States); C. J. Fredricksen, T. Brusentsova, R. E. Peale, Univ. of Central Florida (United States); O. Edwards, Zyberwear, Inc. (United States)

8032 OF On the accuracy of decay constant measurement by swept-cavity heterodyne cavity ringdown spectroscopy [8032-13]

K. K. M. B. D. Silva, A. van der Walt, J. M. Dell, L. Faraone, The Univ. of Western Australia (Australia)

\section{SESSION 4 RAMAN, SERS, AND SECURITY APPLICATIONS}

8032 OG Rapid and field-deployable biological and chemical Raman-based identification [8032-14] E. Botonjic-Sehic, Morpho Detection (United States); T. L. Paxon, GE Global Research (United States); H. Boudries, Morpho Detection (United States)

$8032 \mathrm{OH}$ Detection of fire protection and mineral glasses in industrial recycling using Raman mapping spectroscopy [8032-15]

M. De Biasio, T. Arnold, G. McGunnigle, M. Kraft, R. Leitner, Carinthian Tech Research AG (Austria); D. Balthasar, V. Rehrmann, Titech GmbH (Germany)

8032 Ol Toward non-invasive detection of concealed energetic materials in-field under ambient light conditions [8032-16]

B. Cletus, W. Olds, E. L. Izake, P. M. Fredericks, H. Panayiotou, E. Jaatinen, Queensland Univ. of Technology (Australia)

8032 0J Integration of optical devices and nanotechnology for conducting genome research [8032-17]

P.-Y. Chung, P. Parag, Z. Zhu, C. Chegini, G. Schultz, W. Tan, P. Jiang, C. Batich, Univ. of Florida (United States)

8032 OK Application of an ion mobility spectrometer with pulsed ionisation source in the detection of dimethyl methylphosphonate and toluene diisocyanate [8032-18]

W. Baether, Draegerwerk AG \& Co. (Germany); S. Zimmermann, Leibniz Univ. Hannover (Germany); F. Gunzer, The German Univ. in Cairo (Egypt)

8032 OL Development of a fieldable rugged TATP surface-enhanced Raman spectroscopy sensor [8032-19]

K. M. Spencer, S. L. Clauson, J. M. Sylvia, ElC Labs., Inc. (United States)

\section{SESSION 5 NOVEL SPECTROMETERS I}

8032 OM Dual-channel polarization imaging spectrometer [8032-20]

T. Mu, C. Zhang, Xi'an Jiaotong Univ. (China) 
8032 ON Photonic crystal slot waveguide for high sensitivity on-chip near-infrared optical absorption spectroscopy of xylene in water [8032-21]

S. Chakravarty, Omega Optics, Inc. (United States); W.-C. Lai, The Univ. of Texas at Austin (United States); X. Wang, Omega Optics, Inc. (United States); C.-Y. Lin, R. T. Chen, The Univ. of Texas at Austin (United States)

803200 A compact and portable IR analyzer: progress of a MOEMS FT-IR system for mid-IR sensing [8032-22]

A. Kenda, Carinthian Tech Research AG (Austria); S. Lüttjohann, Bruker Optik GmbH

(Germany); T. Sandner, Fraunhofer Institute for Photonic Microsystems (Germany); M. Kraft, A. Tortschanoff, Carinthian Tech Research AG (Austria); A. Simon, Bruker Optik GmbH (Germany)

8032 OP Portable coherent frequency-domain THz spectrometer [8032-23]

R. T. Logan, Jr., J. R. Demers, B. L. Kasper, Emcore Corp. (United States)

$80320 Q$ Compact remote Raman and LIBS system for detection of minerals, water, ices, and atmospheric gases for planetary exploration [8032-24]

A. K. Misra, S. K. Sharma, T. E. Acosta, D. E. Bates, Univ. of Hawai'i (United States)

\section{SESSION 6 NOVEL SPECTROMETERS II}

8032 OS Real-time smart fluorescence sensor platform [8032-26]

J. E. Dickens, M. S. Vaughn, M. Taylor, GlaxoSmithKline (United States); M. Ponstingl, Custom Sensors and Technology (United States)

8032 OU A compact, fast, wide-field imaging spectrometer system [8032-29]

P. Mouroulis, B. E. Van Gorp, V. E. White, J. M. Mumolo, Jet Propulsion Lab. (United States);

D. Hebert, M. Feldman, Lovisiana State Univ. (United States)

8032 OV High-speed resonant FTIR spectrometer [8032-30]

J. Rentz Dupuis, D. Carlson, D. Mansur, T. Evans, R. Vaillancourt, J. Engel, OPTRA, Inc. (United States); B. Engel, Nelson Air Corp. (United States)

\section{SESSION 7 IMAGING AND CHEMOMETRICS}

8032 0W Compact high-resolution VIS/NIR hyperspectral sensor [8032-31]

T. Hyvärinen, E. Herrala, Specim Spectral Imaging Ltd. (Finland); W. Procino,

O. Weatherbee, SpecTIR LLC (United States)

8032 0X Advances in hyperspectral LWIR pushbroom imagers [8032-32]

H. Holma, A.-J. Mattila, T. Hyvärinen, Specim Spectral Imaging Ltd. (Finland);

O. Weatherbee, SpecTIR LLC (United States)

8032 OY Near-infrared imaging spectroscopy for counterfeit drug detection [8032-33]

T. Arnold, M. De Biasio, R. Leitner, Carinthian Tech Research AG (Austria) 
$80320 Z$ Advanced algorithms for the identification of mixtures using condensed-phase FT-IR spectroscopy [8032-34]

J. Arnó, G. Andersson, D. Levy, C. Tomczyk, P. Zou, E. Zuidema, Smiths Detection (United States)

803210 Development of simple algorithm for direct and rapid determination of cotton maturity from FT-IR spectroscopy [8032-35]

Y. Liu, D. Thibodeaux, G. R. Gamble, USDA, Agricultural Research Service (United States)

POSTER SESSION

803211 Sensing of FWHM and peak wavelength for LEDs via low-cost filter-array spectrum sensor [8032-28]

C.-C. Chang, C.-C. Chen, National Taipei Univ. of Technology (Taiwan); U. Kurokawa,

B. I. Choi, Nanolambda Inc. (United States)

803212 Snapshot spectral imaging demonstrator [8032-37]

M. De Biasio, T. Arnold, A. Tortschanoff, R. Leitner, Carinthian Tech Research AG (Austria)

Author Index 


\title{
Conference Committee
}

\author{
Symposium Chair
}

William Jeffrey, HRL Laboratories, LLC (United States)

Symposium Cochair

Kevin P. Meiners, Office of the Secretary of Defense (United States)

Conference Chairs

Mark A. Druy, Physical Sciences Inc. (United States)

Richard A. Crocombe, Thermo Fisher Scientific Inc. (United States)

Program Committee

John M. Dell, The University of Western Australia (Australia)

Erik Deutsch, Block Engineering, LLC (United States)

Richard D. Driver, Headwall Photonics Inc. (United States)

Jason M. Eichenholz, Ocean Optics, Inc. (United States)

Michael B. Frish, Physical Sciences Inc. (United States)

David M. Haaland, Spectral Resolutions (United States)

Fred Haibach, Block Engineering, LLC (United States)

Martin Kraft, Carinthian Tech Research AG (Austria)

Jouko O. Malinen, VTT Optical Instruments (Finland)

Christopher J. Manning, Manning Applied Technologies, Inc. (United

States)

Curtis A. Marcott, Light Light Solutions, LLC (United States)

Robert G. Messerschmidt, Rare Light Inc. (United States)

Ellen V. Miseo, Agilent Technologies, Inc. (United States)

David W. Schiering, Smiths Detection (United States)

Eric B. Takeuchi, Daylight Solutions, Inc. (United States) 
Downloaded From: https://www.spiedigitallibrary.org/conference-proceedings-of-spie on 26 Apr 2023

Terms of Use: https://www.spiedigitallibrary.org/terms-of-use 


\section{Introduction}

The past twenty years have seen a massive investment in photonics, electronics and MEMS, aimed at developing new telecommunications capabilities and innovative consumer products. These investments have lead to advances in miniature optics, light sources, tunable filters, array detectors, fiber optic sensors, and a range of other photonic devices, across the whole electromagnetic spectrum, along with technologies for their mass production. In addition, there have been remarkable developments in handheld consumer electronics (cell phones, RF technology, processors, operating systems, displays, user interfaces, memory, Bluetooth, WiFi, cameras, accelerometers, GPS, etc.). All of these advances are increasingly being exploited in new spectroscopic instruments, and are now poised to be the basis of next generation handheld scientific instruments.

Portable and handheld instruments are being developed that are often more sensitive and selective, smaller, cheaper, and more robust than their laboratory predecessors. Concurrent improvements in analytical theory, data analysis methods and portable processors enable these spectroscopic devices to give specific, actionable, answers to their non-specialist operators. Spectroscopybased systems are now making critical judgments in environments and applications that were unreachable twenty years ago, from hazardous materials to the operating theater, and from field geologists to customs and border personnel.

Advances in array detectors (CCD, CID, InGaAs, InSb, MCT, CMOS, etc.) are enabling a new generation of faster imaging spectrometers, with both laboratory and field applications. Lower-cost infrared arrays have been developed, employing MEMS techniques. Again, advances in spectroscopic data processing are providing the ability to generate answers based on chemical-based images from the mass of data produced. Finally, spectrometers are being coupled to functionalized sensors to detect specific species.

The emphasis in this conference is on advanced technologies for spectroscopic instrumentation, particularly the infrared, near-infrared, and Raman molecular techniques, but also including advances enabling miniature and portable spectrometers across the electromagnetic spectrum, including $x$-ray fluorescence, teraHertz, electron spin resonance, nuclear magnetic resonance and mass spectrometry.

This conference premiered at Optics East 2007 in Boston, MA and is now part of the Defense, Security \& Sensing Symposium. In 2011, the conference spanned two days, and was divided into sessions focusing on: Enabling Technologies; Laser-based and Cavity Ringdown Spectrometry; Raman, SERS and Security 
Applications; Novel Spectrometers; and Imaging and Chemometrics. In all, 34 papers were presented, and we are pleased to be able to bring you 31 of them in these proceedings.

On behalf of our program committee members, we hope that we can count on your participation in a future Next-Generation Spectroscopic Technologies conference.

Mark A. Druy Richard A. Crocombe 